\title{
Molecular based method for the detection and quantification of larvae of the golden mussel Limnoperna fortunei using real-time PCR
}

\author{
NORIYUKi ENDO ${ }^{1, *}$, KANA $\mathrm{SATO}^{2} \&$ YASUYUKI NOGATA $^{1}$ \\ ${ }^{I}$ Environmental Science Research Laboratory, Central Research Institute of Electric Power Industry, Abiko, Chiba, 270-1194 Japan \\ ${ }^{2}$ Civil Engineering Research \& Environmental Studies, Inc., Chiyoda, Tokyo, 101-0052 Japan
}

Received 8 May 2009; Accepted 5 June 2009

\begin{abstract}
A molecular based method for the quantitative detection of larvae of the golden mussel Limnoperna fortunei was developed. Partial nucleotide sequences of the mitochondrial cytochrome c oxidase subunit 1 (CO1) gene in several bivalve species including $L$. fortunei were analyzed. These nucleotide sequences and the CO1 gene for bivalve species found in habitats similar to $L$. fortunei (obtained from the EMBL/Genbank/DDBJ databases) were aligned. Based on these results, L. fortunei-specific primers were designed for amplification. DNA extracted from several bivalve species including $L$. fortunei were subjected to PCR using $L$. fortunei-specific primers, and amplification of the DNA fragment was confirmed only in PCR assays which utilized template DNA from L. fortunei. No DNA fragments were amplified during the PCR of freshwater planktonic sample lacking golden mussel larvae which were collected from Lake Ohshio (Gunma, Japan). Real-time PCR was performed using fluorescent dye (SYBR Green) detection. Threshold cycles correlated well with the template DNA and number of larvae equivalents, and the R-square values of the standard curves were 0.99 and 0.98 , respectively. These results suggest that this real-time PCR-based method can be utilized not only for the identification of $L$. fortunei in a particular habitat, but also for the quantification of larvae of this species in natural environments.
\end{abstract}

Key words: golden mussel, larvae, Limnoperna fortunei, quantitative detection, real-time PCR

The golden mussel Limnoperna fortunei (Dunker) is an invasive freshwater bivalve species that has been identified as contributing towards various ecological and economic problems (Darrigran et al. 1998, Ricciardi 1998, Penchaszadeh et al. 2000, Magara et al. 2001, Boltovskoy et al. 2006, Pie et al. 2006). In 2006, this species was designated as an Invasive Alien Species of Japan due to its adverse effects on ecosystems. During the life cycle of L. fortunei, the planktonic stage is an important phase that facilitates the distribution of this species. Given that the process of detecting larvae in planktonic samples is time-consuming, efficient quantitative detection methods are required. Pie et al. (2006) developed a sensitive method for detecting golden mussel larvae by employing a polymerase chain reaction (PCR)-based approach using a specific primer set: LIMNO.COIR1 and LIMNO.COIF1. Furthermore, Boeger et al. (2007) reported that this method allowed for the detection of 1-5 larvae. This PCR-based detection method, however, cannot be utilized for the accurate quantification of larval samples. Real-time PCR is recognized as an effective tool for the detection and quantification of planktonic organisms. In the present study, we used this technique for the

*Corresponding author: Noriyuki Endo; Email, n-endo@criepi.denken. or.jp quantitative detection of golden mussel larvae.

Since the LIMNO.COIR1 and LIMNO.COIF1 primers (Pie et al. 2006) have not been optimized for real-time PCR assays, primers suitable for real-time PCR were newly designed. Adult L. fortunei were collected at Lake Ohshio (Gunma, Japan). Other bivalve species which were subjected to DNA extraction were collected in Lake Ohshio, Lake Hinuma (Ibaraki, Japan) and river mouth in Japan (see Table 1). The bivalves were fixed in $99.5 \%$ ethanol and stored at $4^{\circ} \mathrm{C}$ until used for DNA extraction. Muscle tissues were collected from each adult bivalve species, and DNA was extracted from each tissue sample using a DNeasy ${ }^{\circledR}$ blood and tissue kit (Qiagen, GmbH, Germany), according to the manufacturer's instructions. The region of the mitochondrial cytochrome c oxidase subunit 1 (CO1) gene was amplified by PCR using an Advantage ${ }^{\circledR} 2$ PCR kit (Clontech Laboratories Inc., CA, USA) and the following primers (Folmer et al. 1994): 5'-GGTCAACAAATCATAAAGATATTGG-3' (LCO1490) and 5'-TAAACTTCAGGGTGACCAAAAAATCA-3' (HCO2198). PCR was performed using the TaKaRa PCR Thermal Cycler Dice ${ }^{\circledR}$ Tp600 (TaKaRa Bio, Shiga, Japan), with initial denaturation at $95^{\circ} \mathrm{C}$ for $1 \mathrm{~min}$, followed by 35 cycles of $95^{\circ} \mathrm{C}$ for $30 \mathrm{~s}, 54^{\circ} \mathrm{C}$ for $30 \mathrm{~s}$, and $68^{\circ} \mathrm{C}$ for $30 \mathrm{~s}$. Direct sequencing was performed on an ABI Prism ${ }^{\circledR}$ 310 genetic analyzer using a BigDye ${ }^{\circledR}$ Terminator Cycle Se- 
Table 1. Bivalve species used for DNA analysis in the present study.

\begin{tabular}{|c|c|c|c|}
\hline \multicolumn{2}{|c|}{$\begin{array}{l}\text { EMBL/Genbank/DDBJ } \\
\text { accession number }\end{array}$} & Collection site & Collection date \\
\hline Limnoperna fortunei (Dunker) & AB498011* & Lake Ohshio, Gunma, Japan & May 2008 \\
\hline Xenostrobus securis (Lamarck) & AB498012* & Lake Hamana, Shizuoka, Japan & April 2008 \\
\hline Mytilus edulis (Linnaeus) & NC006161 & - & - \\
\hline Mytilus galloprovincialis (Lamarck) & AB498013* & Daiba, Tokyo, Japan & May 2008 \\
\hline Mytilus trossulus (Gould) & AB498014* & Minamikayabe, Hokkaido, Japan & January 2009 \\
\hline Perna viridis (Linnaeus) & AB498015* & Daiba, Tokyo, Japan & September 2008 \\
\hline Modiolus modiolus (Linnaeus) & DQ264392 & - & - \\
\hline Musculista senhousia (Benson) & AB498016* & Daiba, Tokyo, Japan & May 2008 \\
\hline Corbicula fluminea (Müller) & AB498017* & Lake Ohshio, Gunma, Japan & October 2008 \\
\hline Corbicula japonica (Prime) & AB498018* & Lake Hinuma, Ibaraki, Japan & February 2009 \\
\hline Crassostrea gigas (Thunberg) & AF177226 & - & - \\
\hline Crassostrea nippona (Seki) & AF300616 & - & - \\
\hline
\end{tabular}

* Nucleotide sequence data reported in this paper.

quencing Ready Reaction kit (Applied Biosystems, CA, USA) and the LCO1490 or HCO2198 primer. The nucleotide sequence data thus obtained were analyzed using ABI Prism ${ }^{\circledR}$ DNA Sequencing Analysis Software (Applied Biosystems). The nucleotide sequence data reported in the present study are available from the EMBL/Genbank/DDBJ databases under accession numbers AB498011-AB498018 (see Table 1). These nucleotide sequences and those of the $\mathrm{CO} 1$ gene for bivalve species found in habitats similar to those of L. fortunei (obtained from the EMBL/Genbank/DDBJ databases) were aligned using CLUSTAL X software (Jeanmougin et al. 1998). Species-specific sequences for L. fortunei were then selected, and following specific primers were designed for real-time PCR: 5'-TCTCTTCATTTAGCTGGTGCGTC-3' (Limf-F) and 5'-CAAAACAGATGTAACTGCAAGAGAC-3' (Limf-R).

The specificity of the primer set was evaluated by performing PCR with DNA extracted from several bivalve species, or from planktonic sample containing or lacking golden mussel larvae as templates. Planktonic sample was collected from Lake Ohshio (Gunma, Japan) in August 20, 2008 using a plankton net (NXX13; diameter of $300 \mathrm{~mm}$ ). The sample was fixed in $99.5 \%$ ethanol, and veligers of golden mussel were collected with microscopic observation. The remnant planktonic sample free from golden mussel larvae was subsequently used in experiments as planktonic sample lacking larvae. A planktonic sample (wet weight, $100 \mathrm{mg}$ ) containing 50 larvae, and planktonic sample (wet weight, $100 \mathrm{mg}$ ) lacking larvae were separately homogenized using a zirconia ball (YTZ ${ }^{\circledR}$ ball; Tosoh Corporation, Tokyo, Japan; $3 \mathrm{~mm}$ diameter). DNA was then extracted from homogenates using the Quick-GeneMini80 and Quick-Gene DNA tissue kit S (FUJIFILM Corporation, Tokyo, Japan), respectively, and subsequently employed as the templates in the PCR analysis. PCR was performed as described above with an annealing temperature of $60^{\circ} \mathrm{C}$ and PCR products were subjected to electrophoresis through a $2 \%$ agarose gel. Gels were then stained with SYBR Safe ${ }^{\mathrm{TM}}$ DNA gel stain (Invitrogen Corporation, CA, USA). As a result, am- plification of the DNA fragments was confirmed in PCR assays which utilized template DNA derived from L. fortunei and planktonic sample containing 50 larvae (Fig. 1). On the other hand, DNA fragments were not amplified when using template DNA derived from the other bivalve species or from the planktonic sample lacking larvae (Fig. 1).

Following this, the specific primer set was utilized for realtime PCR analysis of template DNA extracted from golden mussel adults $(0.25,0.5,2.5,5,10,25$ and $50 \mathrm{ng}$ DNA) and larvae (equivalent to $0.02,0.04,0.1,0.2,0.4$, and 1 individuals). Template DNA was extracted from the larvae using the Quick Gene-Mini80 and Quick Gene DNA tissue kit S following homogenization with a zirconia ball. The real-time PCR was performed using fluorescent dye detection with the Thermal Cycler Dice ${ }^{\circledR}$ Real Time System (TP800; TaKaRa Bio). The amplification was carried out using $\mathrm{SYBR}^{\circledR}$ Premix Ex $\mathrm{Taq}^{\mathrm{TM}}$ (TaKaRa Bio) under the following conditions: $95^{\circ} \mathrm{C}$ for $10 \mathrm{~s}$, followed by 40 cycles of $95^{\circ} \mathrm{C}$ for $5 \mathrm{~s}$ and $60^{\circ} \mathrm{C}$ for $30 \mathrm{~s}$. The threshold cycle $(\mathrm{Ct})$ values, the number of cycles corresponding to the threshold fluorescence, were measured, and standard curves were obtained from the $\mathrm{Ct}$ values. The $\mathrm{Ct}$ values correlated well with template DNA and number of larvae equivalents, and the R-square values of the standard curves were 0.99 and 0.98 , respectively (Fig. 2). These results indicated that real-time PCR performed using Limf-F and Limf-R was effective for the quantification of $L$. fortunei DNA in natural planktonic samples.

In this paper, we have described a real-time PCR-based method that allows for the quantitative detection of golden mussel DNA with high sensitivity and precision. This method can be utilized not only for the identification of $L$. fortunei in a particular habitat, but also for the quantification of larvae of this species in natural environments. 


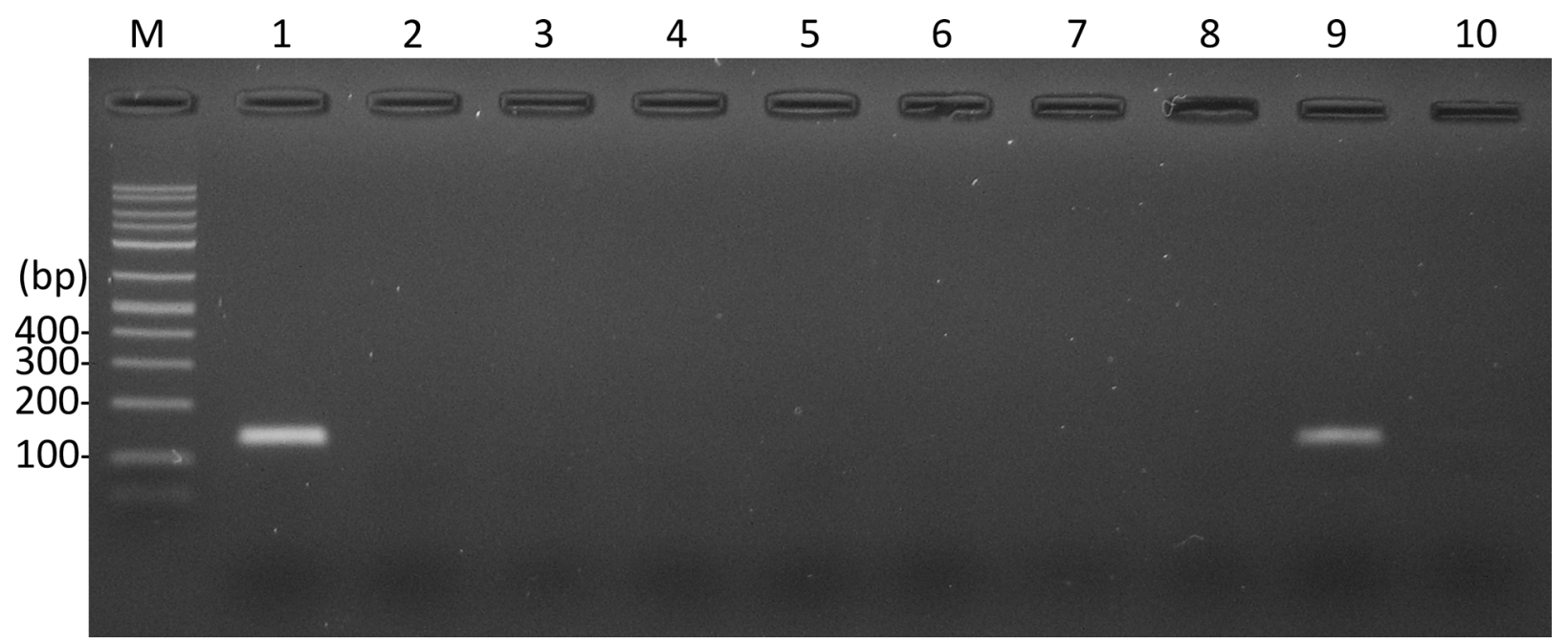

Fig. 1. PCR amplification of the CO1 gene region in 8 bivalve species and planktonic samples containing or lacking golden mussel larvae, using golden mussel-specific primer sets. Lane M, 50-2500 bp DNA markers; lane 1, Limnoperna fortunei; lane 2, Xenostrobus securis; lane 3, Mytilus galloprovincialis; lane 4, Mytilus trossulus; lane 5, Perna viridis; lane 6, Musculista senhousia; lane 7, Corbicula fluminea; lane 8, Corbicula japonica; lane 9, planktonic sample containing 50 L. fortunei larvae; lane 10; planktonic sample lacking L. fortunei larvae.
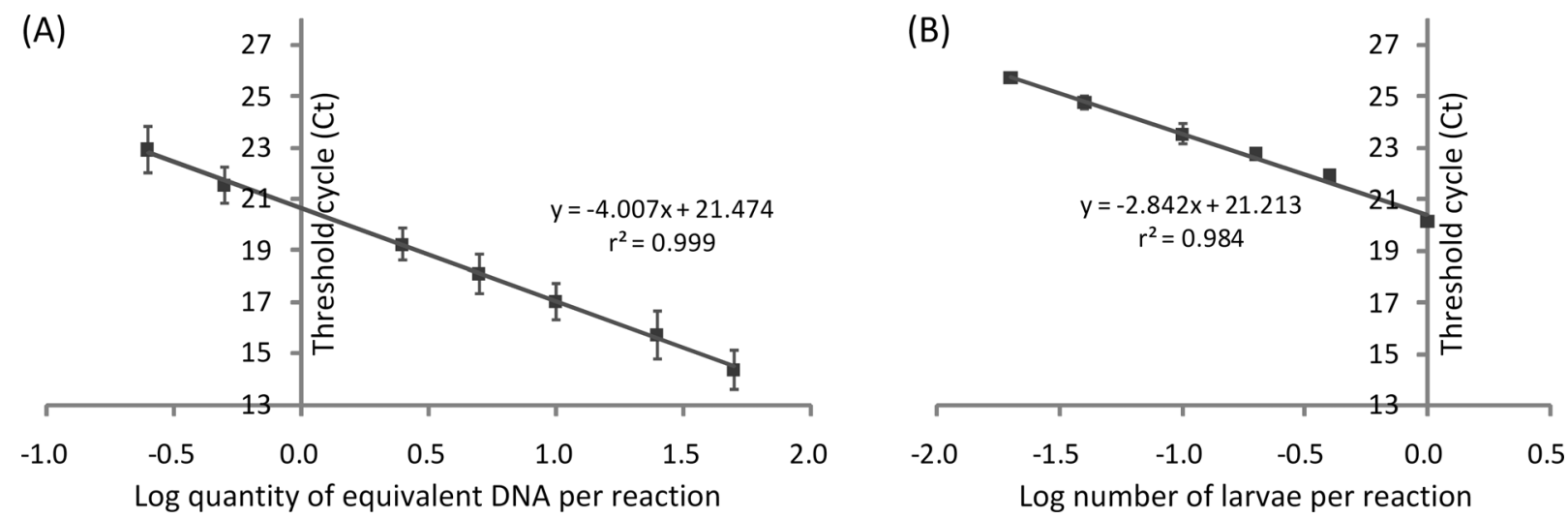

Fig. 2. Real-time PCR standard curves of template DNA extracted from golden mussel adults (A) and larvae (B) using the golden mussel-specific primer set. The threshold cycle values were plotted against the log of the quantity of template DNA (ng) or the number of larvae in the reaction solution. Error bars indicate the standard error of the mean $(n=3)$.

\section{Acknowledgements}

We thank Mr. Tsuyoshi Ohkawara of the Maisaka Oyster Cultivation Union of Lake Hamana (Shizuoka, Japan) for his assistance in the collection several bivalve species. We also thank Dr. Takuya Kobayashi and Dr. Daisuke Nakano of the Environmental Science Research Laboratory, Central Research Institute of Electric Power Industry, for their assistance in the sampling of adult golden mussels and planktonic samples.

\section{References}

Boeger WA, Pie MR, Falleiros RM, Ostrensky A, Darrigran G, Mansur MCD, Belz CE (2007) Testing a molecular protocol to monitor the presence of golden mussel larvae (Limnoperna fortunei) in plankton samples. J Plankton Res 29: 1015-1019.
Boltovskoy D, Correa N, Cataldo D, Sylvester F (2006) Dispersion and ecological impact of the invasive freshwater bivalve Limnoperna fortunei in the Río de la Plata watershed and beyond. Biol Invasions 8: 947-963.

Darrigran G, Martin SM, Gullo B, Armendariz L (1998). Macroinvertebrates associated with Limnoperna fortunei (Dunker, 1857) (Bivalvia, Mytilidae) in Rio de la Plata, Argentina. Hydrobiologia 367: 223-230.

Folmer O, Black M, Hoeh W, Lutz R, Vrijenhoek R (1994) DNA primers for amplification of mitochondrial cytochrome $c$ oxidase subunit I from diverse metazoan invertebrates. Mol Mar Biol Biotechnol 3: 294-299.

Jeanmougin F, Thompson DJ, Gouy M, Higgins DG, Gibson TJ (1998) Multiple sequence alignment with Clustal X. Trends Biochem Sci 23: 403-405.

Magara Y, Matsui Y, Goto Y, Yuasa A (2001) Invasion of the non-indigenous nuisance mussel, Limnoperna fortunei, into water supply facilities in Japan. Journal of Water Supply: Research and Technology-AQUA 50: 113-124.

Penchaszadeh PE, Darrigran D, Angulo C, Averbuj A, Brögger M, 
Dogliotti A, Pírez N (2000) Predation of the invasive freshwater mussel Limnoperna fortunei (Dunker, 1857) by the fish Leporinus obtusidens Valenciennes, 1846 (Anostomidae) in the Rio de la Plata, Argentina. J Shellfish Res 19: 229-231.

Pie MR, Boeger WA, Patella L, Falleiros RM (2006) A fast and accurate molecular method for the detection of larvae of the golden mussel
Limnoperna fortunei (Mollusca: Mytilidae) in plankton samples. J Molluscan Stud 23: 218-219.

Ricciardi A (1998) Global range expansion of the Asian mussel Limnoperna fortunei (Mytilidae): Another fouling threat to freshwater systems. Biofouling 13: 97-106. 